\title{
Product expertise versus professional expertise: Congruency between an endorser's chosen profession and the endorsed product
}

Received (in revised form): 26th May, 2008

\section{Jennifer Christie Siemens}

is an assistant professor in the School of Business Administration at the University of Dayton.

\section{Scott Smith}

is an assistant professor in the Harmon College of Business Administration at the University of Central Missouri.

\section{Dan Fisher}

is an assistant professor in the College of Business at the University of Central Arkansas.

\section{Thomas D. Jensen}

is Professor of Marketing and Wal-Mart Lecturer in Retailing in the Sam M. Walton College of Business at the University of Arkansas.

Keywords endorsers, branding, congruency, attitudes, familiarity

\begin{abstract}
The purpose of this study was to investigate whether individuals could distinguish between profession-related expertise and nonprofession-related expertise, and the implications of this distinction on perceived credibility. An experimental study investigated the effects of congruency between an endorser's expertise related to their profession and the expertise gained from product usage not related to their profession. Subjects were able to make the distinction, and product congruency affected both types of perceived expertise. The effect of congruency on attitudes was mediated by perceived endorser credibility. When using a familiar endorser, brand attitudes were more favourable when the product was congruent with the endorser's profession. On the other hand, brand attitudes were not as affected by congruency when the endorser was unfamiliar. Surprisingly, both an endorser's perceived product expertise and expertise within their profession were lower when endorsing an incongruent product.
\end{abstract}

Journal of Targeting, Measurement and Analysis for Marketing (2008) 16, 159-168. doi:10.1057/jt.2008.8;

published online 7 July 2008

\section{INTRODUCTION}

'Ask the experienced rather than the learned.' (Arabic proverb, unknown author)

The selection of a product endorser is a frequently incorporated advertising method aimed

Correspondence: Jennifer Christie Siemens, University of Dayton, USA. Tel: +9372291086

Fax: +9372293788

E-mail: jennifer.siemens@notes.udayton.edu at influencing consumer perceptions and purchase intentions. It has been estimated that 25 per cent of all advertisements use celebrity endorsements and approximately 10 per cent of all television advertising expenditures are used to pay for celebrity endorsements of products. ${ }^{1}$ The perceived credibility of the endorser plays an important role in a message's persuasive power. Consumers' perception of the credibility of an endorser has been shown to play an important 
role in ad and brand attitude formation as well as change. ${ }^{2-4}$ Silvera and Austad ${ }^{5}$ found that when consumers inferred that an endorser genuinely liked the product they endorsed, attitudes toward the product were more favourable. Premeaux ${ }^{6}$ found that using celebrity endorsers helps ads stand out, makes them more memorable and enhances brand awareness. Given the relationship between credibility and brand/ad attitudes, it is important to identify the antecedents that affect credibility and therefore impact brand and ad attitudes. ${ }^{7,8}$

Credibility has traditionally been conceptualised and measured using three dimensions: expertise, trustworthiness and attractiveness. ${ }^{9}$ Research has shown support for these three dimensions of credibility as well as a relationship between credibility, brand and ad attitudes, and purchase intentions. ${ }^{9-11}$ This body of research has, however, yet to further investigate the possibility of expertise, with regard to credibility as outlined by Ohanian, ${ }^{9}$ having product or profession delineations. Specifically, the consumer's ability to evaluate the various aspects of credibility has not been investigated. . $^{30,12,13}$ Of particular interest to this study is the concept of expertise related to an endorsers experience with a product or within a particular profession. According to Hovland et al., ${ }^{14}$ expertise is 'the extent to which a communicator is perceived to be a source of valid assertions'.

Although research has addressed how expertise is acquired (eg knowledge versus experience), ${ }^{15}$ little research is available on the role of different 'types' of expertise (with a product or within a profession) and their effects on persuasion in an endorser context. Do consumers evaluate expertise relative to an endorser's profession or relative to another form of expertise, such as expertise gleaned from experience in extensively using the product? For example, a hairdresser may have expertise in recommending a hair care product for customers with long hair, even if he or she has short hair, because of his or her professional designation/expertise. On the other hand, 'Joe/Jane Average' may not have any professional expertise in regards to hair care for long hair, but has been using a hair care product for a long time and therefore has product expertise only through extensive use of the product. To what extent are these individuals viewed as an expert for these products? How does an endorser's expertise related to their profession or product usage impact perceptions of endorser credibility? This approach posits that the effectiveness of an endorsement may be

influenced by the subsequent effects of product or professional expertise attributes perceived by consumers.

Boyd and Shank ${ }^{16}$ found that some consumers rated endorsers as more expert when the endorser used the product in their sport; however, they did not investigate whether this product/endorser fit was due to the endorser's extensive product experience or due to his or her expertise within the sport itself. While in some cases product expertise is coupled with one's profession (singer John Mayer endorsing guitars), there are many cases where an endorser is chosen due to an overall image of being good at their profession regardless of any direct product experience (singer John Mayer endorsing GAP clothing). Using a spokesperson not considered appropriate for the endorsed product can have negative implications for advertising strategy. ${ }^{10,12}$ Congruency issues may apply directly when a distinction is made by consumers concerning an endorser's professional versus product expertise.

The purpose of this study is to identify the role of expertise with a product versus expertise based on profession with regard to an endorser's credibility and attitudes toward the endorsed product. Previous studies have suggested that familiarity of the endorser may facilitate the degree to which congruency affects perceived credibility. ${ }^{17}$ As such, this study will also examine the impact of endorser familiarity and congruency between the endorsed product and the endorser's profession on consumer attitudes.

\section{BACKGROUND}

A review of the literature shows that there is little agreement about how expertise is defined. For Hovland et al., ${ }^{14}$ expertise is the extent to which a communicator is perceived to be capable of making correct assertions. McGuire's ${ }^{18}$ expertise involves an individual's perceived ability to know the correct stance on an issue. Alba and 
Hutchinson $^{19}$ require experts to be able to successfully perform product-related tasks. Bettman and Sujan ${ }^{20}$ classify consumers who have prior experience with a specific product as experts, while others ${ }^{21}$ refer to these consumers as being experienced.

Braunsberger and Munch, ${ }^{15}$ following Jacoby et al. ${ }^{22}$ attempted to more precisely define and differentiate between experience and expertise. Jacoby et al. ${ }^{22}$ maintain that an individual can possess considerable experience in a specific area but not be an expert on the subject matter and that individuals' identical levels of expertise may possess differing amounts of experience. Thus, the tendency of previous studies to operationalise expertise based on experience ${ }^{23,24}$ may be confounding. A primary reason for this confusion is that, while both may involve acquiring knowledge, having experience does not always equate to expertise. Jacoby et al. ${ }^{22}$ further maintain that the major distinction between experience and expertise is that the latter involves a qualitatively higher level of knowledge or skill when compared to some external standard. Consequently, Braunsberger and Munch ${ }^{15}$ conclude that experience and expertise are two distinguishable constructs, where experience is a high degree of familiarity with a subject area/ product obtained through some type of exposure while expertise is having a high degree of skill or knowledge of a subject area/product obtained through some type of formal training.

Following Braunsberger and Munch, ${ }^{15}$ the current study examines product expertise, or the expertise one has due to experience with the product. In addition, and extending prior studies, this research also examines 'professional expertise', or the endorser's level of knowledge within his chosen profession (ie the level of expertise that a professional race car driver possesses about car racing). Perceived expertise as a qualified professional in an occupational field may be distinct from a source's perceived expertise with regard to specific product knowledge. For example, a consumer might perceive a professional basketball player's expertise in his occupation of playing the game of basketball to be distinct from his expertise with basketball shoes. Focusing on this distinction further separates Ohanian's 9 credibility scale into these two new subdimensions of expertise.

Theory underlying an endorser's profession or product expertise is closely related to that of a 'match up' or congruency effect. Kanungo and Pang $^{25}$ identify matching of endorser and product characteristics as having important effects on consumer product evaluation. Therefore, spokesperson effectiveness will depend heavily on the 'fittingness' of the endorser to the product being endorsed. Friedman and Friedman ${ }^{26}$ examined the match-up effect of using a specific type of endorser combined with various types of products. They were able to show that a matchup effect is not limited to physical characteristics, but is also applicable to the cultural role of the endorser.

Prior studies have employed social adaptation theory to examine issues of product/endorser match-up or congruency. ${ }^{27,28,10}$ This theory suggests that information's adaptive significance will determine its impact. Thus, perceptions of professional expertise versus product expertise may influence the persuasive power an endorser will have on a consumer. An endorser may convey professional expertise, thus stimulating the consumer to associate use of the product with exemplary performance in a given professional area. Information about a product presented by an endorser should have adaptive significance in guiding a consumer's selection process when the spokesperson-product relationship is congruent.

In their study of attitude persistence under low involvement conditions, Sengupta et al. ${ }^{29}$ stress the importance of identifying a factor that facilitates the formation of strong associative links between an ad cue and the product being advertised. They suggest that product/cue relatedness, defined by Anderson ${ }^{30}$ as the mutual meaningfulness of two nodes in memory, is one such factor. ${ }^{29}$ They further propose that relatedness can be thought of as the fit, relevance and appropriateness of the cue with regard to the product. While Sengupta et al. ${ }^{29}$ looked at product/endorser congruency (or relatedness), familiar endorsers were used in both conditions and perceived endorser credibility was not investigated. Kirmani and Shiv ${ }^{31}$ define 
source congruency as, "the degree of match between accessible endorser associations and attributes associated with the brand', (p. 26). In this instance, source congruency is based on endorser-related attributes that are shared with the product or brand.

While previous studies concerning product/ endorser congruency have focused on product attributes or characteristics being similar or dissimilar to an endorser's image, the current research concerns congruency of the attributes triggered by the endorser's professional area of expertise and the product being endorsed. The importance of this distinction is evident in the frequency of endorsements made by spokespersons for products not related to their profession (eg Michael Jordan endorsing Ball Park hotdogs or Rayovac batteries). Thus a product that is associated with the endorser's profession would be said to have high congruency with the endorser (ie Michael Jordan demonstrates high congruency between his profession and basketball shoes but low congruency with hotdogs).

Kamins and Gupta ${ }^{17}$ suggest that familiarity may facilitate the degree to which congruence affects the internalisation process of social influences. McCracken's ${ }^{32}$ study also suggests that celebrities, or familiar spokespersons, have a greater impact on consumers due to a vivid and identifiable persona. Therefore, a spokesperson should be more attractive to the extent that he or she is perceived to be knowledgeable about the product and its attributes being discussed or advertised.

Firms use well-known endorsers because they feel that the life experiences of the endorser fit the message being conveyed, that the endorser has high appeal with a target consumer group, or that the universal appeal of the endorser creates a universal advertising message. ${ }^{33}$ In addition, success through familiarity requires that the endorser be viewed as different from other celebrities and be seen as relevant to the product and audience. The specified audience should view an endorser as recognisable, likable and friendly. ${ }^{34}$ An unfamiliar endorser, although he or she may possess expertise, may not be seen as credible.

\section{HYPOTHESES}

Ohanian ${ }^{9}$ proposed a measure of endorser credibility consisting of three dimensions: expertise, trustworthiness and attractiveness. A goal of the present research is to further refine this scale in order to test a consumer's ability to distinguish between professional and product expertise of an endorser. So far, no studies in marketing have investigated product/endorser congruency in the context of expertise with the product versus the expertise within the endorser's profession. Based on the previous discussion of product versus professional expertise and source/product congruency, the following hypotheses were developed:

$\mathbf{H}_{1}$ : Overall perceived endorser credibility will be more positive when the product and the endorser's profession are congruent rather than incongruent. As a result, (a) perceptions of endorser's trustworthiness and (b) perceptions of the endorser's expertise with the product will be more positive with congruency.

If the endorser is advertising a product that he or she should be knowledgeable about, consumers should perceive the endorser to be more expert on the product's merits. On the other hand, if an endorser advertises a product that does not fit the consumer's image of the endorser, he will be seen as less trustworthy. Because an endorser's attractiveness consists of his or her salient physical attributes, the product/profession congruency should not affect perceived attractiveness. Similarly, congruency should not change a consumer's perception of an endorser's professional expertise because the endorser's experience with his occupation exists in and of itself.

In addition to the fit between endorser and product, the familiarity of the endorser should be considered. Advertising managers often choose to use celebrity endorsers over noncelebrity endorsers in many contexts. ${ }^{35}$ Therefore, the second hypothesis utilises this basic concept.

$\mathbf{H}_{2}$ : Consumer's perceptions of an endorser's overall credibility will be more positive when the endorser is familiar than when the endorser is unfamiliar. 
Given the previous findings suggesting that source credibility impacts brand and ad attitudes, ${ }^{7,8}$ we further hypothesise that:

$\mathbf{H}_{3}$ : Greater levels of perceived endorser credibility will result in more positive (a) attitudes toward the ad, (b) attitudes toward the brand, (c) attitudes toward the endorser and (d) purchase intentions.

While the previous hypotheses concern direct relationships between the variables, we additionally propose that perceived endorser credibility will mediate the effect of product/ profession congruency on attitudes. The influence of product/profession congruency on attitude toward the brand and ad should be largely due to its effect on endorser credibility. When the variance accounted for by endorser credibility is removed, the main effects proposed in $\mathrm{H}_{1}$ and $\mathrm{H}_{3}$ should be significantly reduced. ${ }^{36}$ Thus, the following is proposed:

$\mathbf{H}_{4}$ : Perceptions of endorser credibility will mediate the effect of product/profession congruency on (a) attitudes toward the brand and (b) attitudes toward the ad.

\section{METHOD}

\section{Participants and procedure}

One hundred and thirty-five male and female subjects, obtained via intercept at a large midwest mall, participated in this study. Subjects were assigned randomly to each cell in a 2 (familiar or unfamiliar endorser) $\times 2$ (congruent or incongruent product/profession) between-subject design. The experiment was conducted in a workstation setting. Participants were given $\$ 3.00$ after completing the study.

Subjects were given a packet containing both a print advertisement and a survey questionnaire. They were instructed to view the ad and then answer all questions. Each ad was similar in arrangement, and contained a picture of a product with two product claims. Each ad also contained a picture of an endorser, the endorser's name and professional credentials, and an identical statement from the endorser praising the product.

\section{Independent variables}

\section{Endorser familiarity}

Endorser familiarity was manipulated by using both a made-up endorser and a celebrity. Chad Kinnear (a person invented by the researchers) served as the unfamiliar endorser and Jeff Gordon (famous race car driver) served as the familiar endorser. Chad Kinnear was said to be a professional downhill snow skier. Jeff Gordon was chosen because of his prominence as a professional racecar driver and also because of his exposure in the media. Gordon has claimed several NASCAR titles and has hauled more than $\$ 16 \mathrm{~m}$ in winnings. He has also served as the celebrity spokesperson for several companies, including Pepsi and Ray-Ban sunglasses.

\section{Product congruency}

Product congruency was defined as the fit between the endorser's profession and the product. Because Jeff Gordon is a racecar driver, car tires were used as a congruent product. For Chad Kinnear, snow skis were used as the congruent product. Thus, from the $2 \times 2$ experimental design, subjects saw one of four ads:

\begin{tabular}{cll}
\hline & Familiar endorser & $\begin{array}{l}\text { Unfamiliar } \\
\text { endorser }\end{array}$ \\
\hline $\begin{array}{c}\text { Congruent } \\
\text { product } \\
\begin{array}{c}\text { Incongruent } \\
\text { product }\end{array}\end{array}$ & Jeff Gordon/tires & $\begin{array}{c}\text { Chad Kinnear/ } \\
\text { snow skis } \\
\text { Chad Kinnear/ } \\
\text { tires }\end{array}$ \\
\hline
\end{tabular}

\section{Dependent variables}

\section{Manipulation checks}

As a check for the endorser familiarity manipulation, subjects were asked to rate their familiarity with the endorser on three 7-point semantic differential scales (eg familiar-unfamiliar, $\alpha=0.95)$.

\section{Endorser credibility}

Subjects rated the endorser on Ohanian's 9 previously established scale for measuring endorser credibility (see Appendix A). This 
credibility scale includes items designed to tap endorser attractiveness, trustworthiness and expertise (see Appendix A for individual items, five per dimension). Attractiveness and trustworthiness dimensions were not altered.

Although correlated $(r=0.51)$, subjects were able to distinguish between product expertise and professional expertise. A two-factor solution for product expertise and professional expertise items with no cross loadings fit the data better $\left(\chi^{2}\right.$ $(32)=37.70, p=0.22$, AGFI $=0.91, \mathrm{CFI}=1.00$, $\mathrm{RFI}=0.98)$ than a single-factor solution $\left(\chi^{2}\right.$ $(31)=528.08, p<0.01$, AGFI $=0.41, \mathrm{CFI}=0.79$, RFI $=0.68)$. Mean scores for each of the four dimensions of source credibility were used for hypotheses testing.

\section{Attitudes and purchase intention}

Multiple item, seven-point semantic differential scales were used to assess four attitudinal dimensions: attitude toward the ad, attitude toward the brand, attitude toward the endorser and purchase intention. Ad attitudes were assessed with six items (eg bad-good, likable-not likable). Brand attitudes were measured with five items (eg interesting-uninteresting, likable-not likable). Attitudes toward the endorser were measured with five items (eg honest-dishonest, favourableunfavourable). Purchase intentions were measured with four items (eg very likely purchase-very unlikely purchase). Attitudes and purchase intention dimension information is presented in Appendix C.

\section{ANALYSIS AND RESULTS}

\section{Manipulation checks}

ANOVA revealed that familiarity with the endorser was significantly greater for Jeff Gordon than for Chad Kinnear, indicating that the familiarity manipulation was effective $(F(1,129)=35.70, p<0.01)$.

\section{Endorser credibility measures}

Collapsing across the four dimensions used to measure credibility (attractiveness, trustworthiness, product expertise and professional expertise), ANOVA revealed a significant effect of product/ profession congruency on overall credibility $(F(1,131)=47.47, p<0.001)$ but not of familiarity or the congruency by familiarity interaction, $F$ 's $<1$ ). Consistent with $\mathrm{H}_{1}$, when the endorser's profession was congruent with the endorsed product subjects perceived the endorser as more credible $(M=5.53)$ than with incongruency $(M=4.28)$. Hypothesis 2 was not supported due to the lack of a significant main effect of familiarity on overall perceived credibility.

Further analyses of the individual credibility scale dimensions were performed using MANOVA. Consistent with the univariate test for overall credibility, multivariate tests revealed a significant main effect of product/profession congruency (Wilks' lambda $F(4,127)=28.37$, $\left.p<0.001, \eta^{2}=0.47\right)$ but not of familiarity or the congruency by familiarity interaction $(p ' s>0.10)$. There was a significant effect of congruency on endorser trust $(F(1,130)=5.22, p<0.05$, $\left.\eta^{2}=0.04\right)$, product expertise $(F(1,130)=94.42$, $\left.p<0.001, \eta^{2}=0.42\right)$ and professional expertise $\left(F(1,130)=24.66, p<0.001, \eta^{2}=0.16\right)$ but not on endorser attractiveness $(F<1)$. Subjects perceived the endorser to be more trustworthy and have higher levels of product expertise and professional expertise when endorsing a congruent product (see Table 1). These results support $\mathrm{H}_{1 \mathrm{a}}$ and $\mathrm{H}_{1 \mathrm{~b}}$.

\section{Attitude measures}

Supporting $\mathrm{H}_{3}$, the overall credibility of the endorser was significantly and positively correlated with attitudes toward the endorser $(r=0.63)$, attitude toward the ad $(r=0.56)$ and attitude toward the brand $(r=0.38)$. Furthermore, attitudes toward the ad and brand were positively correlated with subjects' purchase intentions $(r=0.31)$. For the source credibility dimensions, perceptions of endorser trustworthiness had the highest correlations with attitudes toward the endorser $(r=0.71)$, attitude toward the ad $(r=0.57)$, attitude toward the brand $(r=0.44)$ and purchase intentions $(r=0.24)$. All correlations between the four credibility dimensions and attitude measures were significant.

A MANOVA revealed significant effects of product/profession congruency (Wilks' lambda $\left.F(4,127)=4.55, p<0.01, \eta^{2}=0.13\right)$ and the 
Table 1: Mean credibility ratings by product/profession congruency

\begin{tabular}{lll}
\hline Credibility dimension & $\begin{array}{l}\text { Congruent } \\
\text { product and } \\
\text { profession }\end{array}$ & $\begin{array}{l}\text { Incongruent } \\
\text { product and } \\
\text { profession }\end{array}$ \\
\hline Attractiveness & 4.24 & 4.21 \\
Trustworthiness & 5.16 & 4.66 \\
Product expertise $^{\star *}$ & 6.28 & 3.16 \\
Profession expertise $^{\star *}$ & 6.54 & 5.09 \\
Overall credibility $^{\star *}$ & 5.53 & 4.28 \\
\hline
\end{tabular}

${ }^{*} p<0.05,{ }^{* *} p<0.001$.

Higher means indicate more favourable ratings. Items rated on seven-point scale.

congruency by familiarity interaction (Wilks' lambda $\left.F(4,127)=6.06, p<0.001, \eta^{2}=0.16\right)$ on overall attitudes. Familiarity was not, however, found to directly affect attitudes (Wilks' lambda $F(4,127)=1.80, p>0.10)$. ANOVAs revealed significant main effects of congruency for attitudes toward the endorser $(F(1,130)=3.98$, $\left.p<0.05, \eta^{2}=0.03\right)$, attitudes toward the ad $(F(1$, $\left.130)=15.57, p<0.001, \eta^{2}=0.11\right)$, attitudes toward the brand $\left(F(1,130)=8.82, p<0.01, \eta^{2}=0.06\right)$ and purchase intentions $(F(1,130)=6.85, p=0.01$, $\left.\eta^{2}=0.05\right)$. Attitudes and purchase intentions were more favourable when the endorsers' profession was congruent with the product being endorsed. The congruency main effects were qualified by significant or marginally significant interactions of congruency and familiarity for attitudes toward the endorser $\left(F(1,130)=2.56, p=0.11, \eta^{2}=0.02\right)$, attitudes toward the brand $(F(1,130)=16.37$, $\left.p<0.001, \eta^{2}=0.11\right)$ and purchase intentions $(F(1$, $\left.130)=3.33, p=0.07, \eta^{2}=0.02\right)$. Illustrated in Table 2, simple main effects revealed significant effects of product/profession congruency for familiar endorsers $(p$ 's $<0.01)$ that were not present for unfamiliar endorsers ( $p$ 's $>0.10)$. Attitudes and purchase intentions were less favourable for familiar endorsers when the endorsed product was incongruent with the endorser's profession as compared to when endorsing products congruent with their profession.

In order to test $\mathrm{H}_{4}$, separate coefficients for three regression equations were estimated and tested, as specified by Baron and Kenny. ${ }^{36}$ First, the proposed mediator (endorser credibility) was regressed on the independent variable (product/ profession congruency). Secondly, the dependent variables (ad and brand attitudes) were regressed on the independent variable (product/profession congruency). Finally, the dependent variables (ad and brand attitudes) were regressed on both the independent variable (congruency) and the proposed mediator (credibility). The results are shown in Table 3. The results are significant for each of the three regressions, with $R^{2}$ values of 0.14 for brand attitudes and 0.34 for ad attitudes. As proposed in $\mathrm{H}_{4}$, endorser credibility has a significant mediating effect ( $t$-values ranging from 3.89 to $6.93, p<0.001$ for all) for each of the ad and brand attitudes, and in each case the main effect of congruency becomes nonsignificant with the inclusion of endorser credibility as a mediator. These results indicate that perceptions of endorser credibility can account for main effects of product/profession congruency on brand and ad attitudes. The findings offer support for $\mathrm{H}_{4}$.

\section{DISCUSSION}

The results of this research present several interesting findings. First, an important contribution of this research is the distinction of two dimensions of expertise. The ability of

Table 2: Means attitude and purchase intentions*

\begin{tabular}{|c|c|c|c|c|}
\hline & \multicolumn{2}{|c|}{ Congruent product/profession } & \multicolumn{2}{|c|}{ Incongruent product/profession } \\
\hline & $\begin{array}{l}\text { Familiar } \\
\text { endorser }\end{array}$ & $\begin{array}{l}\text { Unfamiliar } \\
\text { endorser }\end{array}$ & $\begin{array}{l}\text { Familiar } \\
\text { endorser }\end{array}$ & $\begin{array}{l}\text { Unfamiliar } \\
\text { endorser }\end{array}$ \\
\hline Attitude toward the endorser & 2.66 & 3.02 & 3.46 & 3.11 \\
\hline Attitude toward the ad & 3.43 & 3.42 & 4.11 & 4.03 \\
\hline Attitude toward the brand & 2.49 & 2.81 & 3.80 & 2.61 \\
\hline Purchase intention & 3.29 & 3.57 & 4.80 & 3.84 \\
\hline
\end{tabular}

*Higher means indicate more favourable ratings. Items rated on seven-point scale. 
Table 3: Tests of the mediating role of endorser credibility

\begin{tabular}{|c|c|c|c|c|}
\hline & \multicolumn{4}{|l|}{ Dependent variables } \\
\hline & \multicolumn{2}{|l|}{ Brand attitudes } & \multicolumn{2}{|l|}{ Ad attitude } \\
\hline & Standardised coefficient & $t$-value & Standardised coefficient & $t$-value \\
\hline \multicolumn{5}{|c|}{ Proposed mediator } \\
\hline Credibility & 0.376 & 3.89 & 0.587 & 6.93 \\
\hline \multicolumn{5}{|c|}{ Independent variable } \\
\hline Congruency & 0.029 & 0.302 & 0.006 & 0.069 \\
\hline Model F & 11.73 & & 34.53 & \\
\hline Adj. $R^{2}$ & 0.14 & & 0.34 & \\
\hline
\end{tabular}

respondents to distinguish between professional expertise and product expertise is an important extension of prior research regarding endorser credibility. While endorser expertise has been treated as a single dimension in the past, our findings suggest that this may not be the case.

As expected, the congruency between product experience and an endorser's profession significantly impacted overall perceptions of credibility. While it was expected that perceptions of endorser trustworthiness and product expertise would be less favourable with incongruency, it was not anticipated that perceptions of professional expertise would change. Surprisingly, it was found that consumer perceptions of an endorser's job-related expertise also decreased under conditions of product incongruency. Jeff Gordon's expertise as a racecar driver decreased when he endorsed snow skis, an incongruent product. This may be due to the fact that consumer perceptions of job-related expertise are derived to some extent by perceptions of professional expertise presented through advertising. Jeff Gordon may be perceived as more of an expert at racing because the manufacturers of Goodyear, a related product, have asked him to endorse their product. On the other hand, he would not be perceived as a more expert racecar driver when endorsing K2 skies, an incongruent product. Another interesting finding was that endorser familiarity had no impact on perceptions of overall credibility. Thus Jeff Gordon, an established racecar driver, was perceived as no more credible than Chad Kinnear, a fictitious downhill skier.
Another important contribution of this research is the interaction between product/ profession congruency and endorser familiarity for brand attitudes. When using a familiar endorser, consumers' attitudes toward the brand were more favourable when the product was congruent with the endorser's profession. On the other hand, brand attitudes were not as affected by congruency when the endorser was unfamiliar. Consumers preferred the use of an unfamiliar endorser when incongruency was present in the ad. This finding makes sense within the context of social adaptation theory. Consumers view Jeff Gordon as an effective source of information about tires due to his known experience with that product. Jeff Gordon's inclusion in the advertisement for tires may have suggested the idea that use of the endorsed product would increase consumers' driving ability, as it seemingly did for the endorser. The same message is, however, not conveyed when Jeff Gordon endorses skis because he is not known to have experience within this field. Advertising implications for this result indicate that if the product/profession relationship is not congruent, the selection of an unfamiliar endorser may be appropriate. Likewise, endorsers should recognise that advertising an incongruent product could lower both their own and the advertiser's perceived credibility.

Finally, consistent with previous research, a link was found between credibility and brand and ad attitudes. ${ }^{7,8}$ As perceived credibility increased, attitudes toward the brand, the ad, and purchase intentions improved. 


\section{Limitations and suggested future research}

Several potential limitations exist regarding the current study, leading to various opportunities for future research. The current study uses existing brands, where subjects may have had previous experience with the product that could contribute to their attitudes and purchase intentions. Use of fictitious brands would add to the validity of the profession and product expertise differentiation.

Future research should also further explore the expertise dimensions proposed here. While this study has demonstrated two distinct dimensions of endorser expertise (product and profession expertise), it has not been investigated as to how an endorser can acquire expert status on these dimensions. While research has suggested that an endorser gains product expertise through either education about or experience with a product, ${ }^{15}$ future research could investigate whether the manner in which product expertise is gained has an impact on the level of expertise attributed to the endorser. For example, would consumers view a marathon runner as more or less of an expert on protein drinks than a dietitian? Both endorsers could make the claim that the protein drink gives you energy if consumed before a long run. Any differences in perceived credibility of the claim might be due to the way in which the product expertise was gained (ie the marathon runner gains expertise through product experience and the dietitian gains expertise through education). Information regarding such distinctions could prove useful when attempting to select credible endorsers, and would have implications for advertising strategy.

\section{References}

1 Sherman, S. P. (1985) 'When you wish upon a star', Fortune, August 19, pp. 66-71.

2 Walley, W. (1987) 'Actors Set Contract Talks', Advertising Age, December 21, p. 4.

3 Homer, P. M. and Kahle, L. R. (1990) 'Source expertise, time of source identification, and involvement in persuasion: An elaborative processing perspective', Journal of Advertising, Vol. 19, No. 1, pp. 30-39.

4 La Eerie, C. and Choi, S. M. (2005) 'The importance of perceived endorser credibility in South Korean advertising', Journal of Current Issues and Research in Advertising, Vol. 27, No. 2, pp. $67-81$.
5 Silvera, D. H. and Austad, B. (2004) 'Factors predicting the effectiveness of celebrity endorsement advertisements', European Journal of Marketing, Vol. 38, pp. 1509-1526.

6 Premeaux, S. R. (2005) 'The attitudes of middle class male and female consumers regarding the effectiveness of celebrity endorsers', Journal of Promotion Managment, Vol. 11, No. 4, pp. 33-48.

7 Tripp, C., Jensen, T. D. and Carlson, L. (1994) 'The effects of multiple product endorsements by celebrities on consumers' attitudes and intentions', Journal of Consumer Research, Vol. 20, No. 4, pp. 535-547.

8 Atkin, C. and Block, M. (1983) 'Effectiveness of celebrity endorsers', Journal of Advertising Research, Vol. 23 (February/ March), pp. 57-61.

9 Ohanian, R. (1990) 'Construction and validation of a scale to measure celebrity endorsers' perceived expertise, trustworthiness, and attractiveness', Journal of Advertising, Vol. 19, No. 3, pp. 39-52

10 Kahle, L. R. and Homer, P. M. (1985) 'Physical attractiveness of the celebrity endorser: A social adaptation perspective', Journal of Consumer Research, Vol. 11, No. 4, pp. 954-961.

11 Pornpitakpan, C. (2003) 'Validation of the celebrity endorsers' credibility scale: Evidence from Asians', Journal of Marketing Management, Vol. 19 (February), pp. 179-195.

12 Kamins, M. A. (1990) "An investigation into the "Match-Up" hypothesis in celebrity advertising: When beauty may be only skin deep', Journal of Advertising, Vol. 19, No. 1, pp. 4-13.

13 Till, B. D. and Shimp, T. A. (1998) 'Endorsers in advertising: The case of negative celebrity information', Journal of Advertising, Vol. 27, No. 1, pp. 67-82.

14 Hovland, C., Janis, I. and Kelley, H. (1953) 'Communication and Persuasion', 2nd edn, Yale University Press, New Haven, CT.

15 Braunsberger, K. and Munch, J. M. (1998) 'Source expertise versus experience effects in hospital advertising', Journal of Services Marketing, Vol. 12, No. 1, pp. 23-38.

16 Boyd, T. C. and Shank, M. D. (2004) 'Athletes as product endorsers: The effect of gender and product relatedness', Sport Marketing Quarterly, Vol. 13, No. 2, pp. 82-93.

17 Kamins, M. A. and Gupta, K. (1994) 'Congruence between spokesperson and product type: A matchup hypothesis perspective', Psychology and Marketing, Vol. 11, No. 6, pp. $569-587$.

18 McGuire, W. J. (1969) 'The nature of attitudes and attitude change', The Handbook of Social Psychology, Vol. 3, pp. 372-398.

19 Alba, J. W. and Hutchinson, J. W. (1987) 'Dimensions of consumer expertise', Journal of Consumer Research, Vol. 13, No. 4, pp. $411-454$.

20 Bettman, J. R. and Sujan, M. (1987) 'Effects of framing on evaluation of comparable and noncomparable alternatives by expert and novice consumers', Journal of Consumer Research, Vol. 14, No. 2, pp. 141-154.

21 Hoch, S. J. and Ha, Y. -W. (1986) 'Consumer learning: Advertising and the ambiguity of product experience', Journal of Consumer Research, Vol. 13 (September), pp. 221-233.

22 Jacoby, J., Troutman, T., Kuss, A. and Mazursky, D. (1986) 'Experience and expertise in complex decision making', in Richard J.L. (ed.), 'Advances in Consumer Research', Vol. 13, Association for Consumer Research, Provo, UT, pp. 469-475.

23 Brock, T. C. (1965) 'Communicator-recipient similarity and decision change', Journal of Personality and Social Psychology, Vol. 1, pp. 650-654.

24 Woodside, A. and Davenport, J. (1974) 'The effect of salesman similarity and expertise on consumer purchasing behavior', 
Journal of Marketing Research, Vol. 11 (February/March), pp. 198202.

25 Kanungo, R. N. and Pang, S. (1973) 'Effects of human models on perceived product quality', Journal of Applied Psychology, Vol. 57, No. 2, pp. 172-178.

26 Friedman, H. H. and Friedman, L. (1979) 'Endorser effectiveness by product type', Journal of Advertising Research, Vol. 19, No. 5, pp. 63-71.

27 Kahle, L. R. (1984) 'Attitudes and Social Adaptation: A PersonSituation Interaction Approach', Pergamon, Oxford.

28 Kahle, L. R. and Trimmer, S. G. (1983) 'A theory and a method of studying values', in L. R. Kahle (ed.), 'Social Values and Social Change: An Adaptation to Life in America', Praeger, New York.

29 Sengupta, J., Goodstein, R. and Boninger, D. (1997) 'All cues are not created equal: Obtaining attitude persistence under lowinvolvement conditions', Journal of Consumer Research, Vol. 23, No. 3, pp. 351-361.

30 Anderson, J. R. (1990) 'Cognitive Psychology and its Implications', 3rd edn, Freeman, New York.

31 Kirmani, A. and Shiv, B. (1998) 'The effects of source congruity on brand attitudes and beliefs: The moderating role of issuerelevant elaboration', Journal of Consumer Psychology, Vol. 7, No. 1, pp. 25-47.

32 McCracken, G. (1989) 'Who is the celebrity endorser? Cultural foundations of the endorsement process', Journal of Consumer Research, Vol. 16, No. 3, pp. 310-321.

33 Mathur, L. K., Mathur, I. and Rangan, N. (1997) 'The wealth effects associated with a celebrity endorser: The Michael Jordan Phenomenon', Journal of Advertising Research, Vol. 37, No. 3, pp. 67-73.

34 Miciak, A. R. and Shanklin, W. L. (1994) 'Choosing celebrity endorsers', Marketing Management, Vol. 3, No. 3, pp. 50-59.

35 Nataraajan, R. and Chawla, S. K. (1997) 'Fitness marketing: Celebrity or non-celebrity endorsement?' Journal of Professional Services Marketing, Vol. 15, No. 2, pp. 119-129.

36 Baron, R. M. and Kenny, D. A. (1986) 'The moderator-mediator variable distinction in social psychological research: Conceptual, strategic and statistical considerations', Journal of Personality and Social Psychology, Vol. 51, pp. 1173-1182.

\section{Appendix A}

See Table A1.

Table A1: Scales used to assess endorser credibility*

\begin{tabular}{l}
\hline Attractiveness \\
Attractive - unattractive \\
Classy - not classy \\
Beautiful - ugly \\
Elegant - plain \\
Sexy - not sexy \\
Trustworthiness \\
Dependable - undependable \\
Honest - dishonest \\
Reliable - unreliable \\
Sincere - insincere \\
Trustworthy - untrustworthy \\
\hline
\end{tabular}

Table A1: Continued

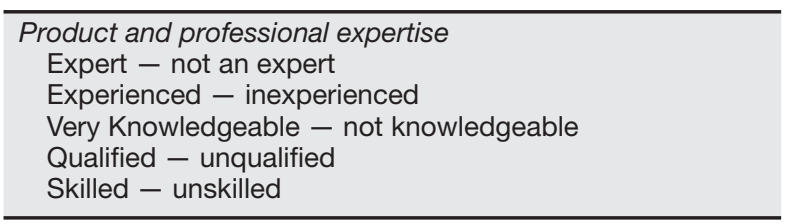

${ }^{*}$ Scale items adapted from Ohanian. ${ }^{9}$ Note, product and professional expertise measured separately but using same semantic differential anchors.

\section{Appendix B}

See Table B1.

Table B1: Endorser credibility manipulation check

\begin{tabular}{|c|c|c|}
\hline $\begin{array}{l}\text { Credibility } \\
\text { dimension }\end{array}$ & Alpha & $\begin{array}{l}\text { Confirmatory } \\
\text { factor analysis* }\end{array}$ \\
\hline Attractiveness & 0.88 & $\chi^{2}(160)=188.90$ \\
\hline Trustworthiness & 0.95 & $p=0.06$ \\
\hline Product expertise & 0.80 & $\mathrm{AGFI}=0.85$ \\
\hline $\begin{array}{l}\text { Profession } \\
\text { expertise }\end{array}$ & 0.98 & $\mathrm{CFI}=0.99$ \\
\hline Overall credibility & 0.85 & $\mathrm{RFI}=0.94$ \\
\hline
\end{tabular}

*All item loadings were significant. Correlations between the factors were significant, ranging between $r=0.21$ (trust and professional expertise) and $r=0.54$ (trust and attractiveness), with the exception of the correlation between professional expertise and attractiveness $(r=0.11, t=1.23)$.

\section{Appendix C}

\section{See Table C1.}

Table C1: Attitude and purchase intention manipulation check

\begin{tabular}{|c|c|c|}
\hline Attitudinal dimension & Alpha & $\begin{array}{l}\text { Confirmatory } \\
\text { factor analysis* }\end{array}$ \\
\hline Attitude toward the Ad & 0.76 & $\chi^{2}(120)=140.63$ \\
\hline Attitude toward brand & 0.88 & $p=0.10$ \\
\hline Attitude toward endorser & 0.90 & $A G F I=0.86$ \\
\hline Purchase intent & 0.78 & $\mathrm{CFI}=0.99$ \\
\hline & & $\mathrm{RFI}=0.91$ \\
\hline
\end{tabular}

*All item loadings were significant. One item did load on two factors. That item, designed to measure attitude toward the ad using good and bad as the endpoints, loaded significantly on attitude toward the endorser and attitude toward the ad. A separate item, anchored by good and bad for measuring attitude toward the endorser, had a higher loading on that dimension than the corresponding item from the attitude toward the ad dimension. Correlations between the four factors were significant and ranged from $r=0.37$ (attitude toward the endorser and purchase intentions) to $r=0.62$ (attitudes toward the ad and brand). Mean scores were calculated for each of the four dimensions and were used in subsequent analyses. 